\title{
Creatine kinase serum activity in feline hyperthyroidism
}

\author{
Atividade sérica da creatinina quinase no hipertireoidismo felino
}

\author{
Mauro José Lahm Cardoso ${ }^{\mathrm{I}^{*}}$ Fabiano Séllos Costa $^{\mathrm{II}}$ Luciane Holsback $^{\mathrm{I}}$ \\ Thais Helena Constantino Patelli $^{\mathrm{I}}$ Maíra Melussi ${ }^{\mathrm{II}}$ Ademir Zacarias Júnior ${ }^{\mathrm{I}}$ Rafael Fagnani $^{\mathrm{IV}}$
}

\begin{abstract}
The aim of this study is to determine the occurrence of creatine kinase $(C K)$ serum activity in cats with hyperthyroidism and its associations with clinical-pathological alterations and with total (TT4) and free (FT4) thyroxin. CK serum activity was evaluated in 19 cats with spontaneous hyperthyroidism, with TT4 ranging from 34.88-294.98nmol $L^{-1}$ and FT4 ranging from 2.83-52.9pmol $L^{-1}$ and also by serum biochemical analysis, including the activity of $C K$, alanine aminotransferase (ALT), alkaline phosphatase (ALP), aspartate aminotransferase (AST), gamma-glutamyl transferase $(G G T)$, cholesterol and bile acids. The reference value for $C K$ considered in this study was of 110-250U $L^{-1}$. CK serum activity was evaluated in 19 cats with spontaneous hyperthyroidism, with TT4 ranging from 34.88-294.98nmol $L^{-1}$ and FT4 ranging from 2.83-52. 9 pmol $L^{-1}$. Its activity $C K$ was elevated in $47.3 \%$ of cats $\left(\geq 250 U L^{-1}\right)$ and presented statistical difference $(P<0.05)$ between cats with or without cardiac disease. $C K$ presented weak association with all parameters in biochemical analysis. In this study, it was not possible to establish a clear association between hyperthyroidism and the increase of $C K$. However, it is important to highlight the inclusion of $C K$ activity in the routine examinations for the evaluation of hyperthyroidism and for further studies to be developed.
\end{abstract}

Key words: thyroid, cats, cardiac disease, thyroxine.

RESUMO

O hipertireoidismo é uma doença endócrina comum em gatos, resultante da excessiva secreção dos hormônios tireoidianos (tiroxina-T4 e triiodotironina-T3), possui caráter multissistemico e provoca várias alterações nos parametros bioquímicos. A creatina quinase (CK) é uma enzima que tem sua atividade sérica aumentada em diversas enfermidades e, na medicina veterinária, é principalmente utilizada para avaliar lesões no músculo esquelético, músculo cardíaco e tecido hepático. O objetivo deste estudo foi determinar a ocorrência da atividade sérica da CK em gatos com hipertireoidismo e suas associações com alterações clínico-patológicas e com a tiroxina total (TT4) e livre (FT4). A atividade sérica da CK foi avaliada em 19 gatos com hipertireodismo espontâneo, com TT4 variando de 34,88$294,98 \mathrm{nmol} L^{-1}$ e FT4 variando de 2,83-52,9nmol $L^{-1}$. Sua atividade estava elevada em $47,3 \%$ dos gatos $\left(\geq 250 U L^{-1}\right)$ e apresentou diferença estatística $(P<0,05)$ entre gatos com ou sem doença cardíaca. A CK apresentou associação fraca com os paramêtros bioquímicos avaliados. Neste estudo, não foi possível estabelecer uma associação clara entre o hipertireoidismo e o aumento da CK. Contudo, os resultados encontrados da atividade da CK encorajam a realização de novos estudos, para uma compreensão mais profunda da elevação da CK no hipertireoidismo.

Palavras-chave: tireoidismo, gatos, doença cardíaca, muscular, tiroxina.

\section{INTRODUCTION}

In veterinary medicine, creatine kinase (CK) serum activity is used mainly to evaluate the damages to the skeletal muscle, and in lesser extent, in cardiac alterations (AKTAS et al., 1995; SCHOBER et al., 1999; DINIZ et al., 2007). Serum CK activity is extensively studied in horses, cattle and dogs (HOFFMANN \& SOLTER, 2008; STOCKHAM $\&$ SCOTT, 2008). It is also used to interpret the serum activity of other enzymes, including aspartate aminotransferase (AST), alanine aminotransferase (ALT) and lactate dehydrogenase (LDH). CK serum activity is routinely evaluated in cats. However, there

'Departamento Veterinária e Produção Animal (DVPA), Centro de Ciências Agrárias (CCA), Campus Luiz Menghel (CLM), Universidade Estadual do Norte do Paraná (UENP), 86360-000, Bandeirantes, PR, Brasil. E-mail:maurolahm@ gmail.com.*Autor para correspondência. IIDepartamento de Medicina Veterinária, Universidade Federal Rural de Pernambuco (UFRPE), Recife, PE, Brasil.

"IIEspaço Vida Veterinária, Londrina, PR, Brasil.

${ }^{\text {IV }}$ Curso de Medicina Veterinária, Universidade do Norte do Paraná (UNOPAR), Londrina, PR, Brasil. Received 07.02.13 Approved 05.15.14 Returned by the author 07.31.14 CR-2013-0902.R3 
is few studies of the evaluation of the frequency of its elevation. Only one study evaluated its diagnostic and prognostic value, or its association with specific diagnoses (HOFFMANN \& SOLTER, 2008; STOCKHAM \& SCOTT, 2008; AROCH et al., 2010), and hyperthyroidism does not feature among them.

The interpretation of the increase in $\mathrm{CK}$ serum activity must be careful, since the spurious increase of $\mathrm{CK}$ can be resulting from in vitro haemolysis. Also, kittens have a higher reference interval for CK activity than adult cats (HOFFMANN \& SOLTER, 2008; STOCKHAM \& SCOTT, 2008) and humans (LIMA et al., 2012; McGROWDER et al., 2011). Infectious diseases, kidney diseases, inflammatory diseases, hepatic lipidosis, traumatism, neoplasia, intramuscular injections and contention are other common causes of increase in CK activity in cats (LEVY et al., 2006; AROCH et al., 2010).

Hyperthyroidism is a multi-systemic clinical alteration resulting from excessive concentration of thyroidal hormones (T3 and T4) and it is considered the most common endocrine disease in domestic cats (MOONEY et al., 1996). Hyperthyroid cats are initially active or hyperactive with normal appetite. With the progression of the disease, they might present weight loss, polyphagia, vomit, polyuria, polydipsia, hyperactivity, diarrheal or bulky stool, weakness, dyspnoea and panting (CARDOSO et al., 2005). In the evaluation of the animal with suspicion of hyperthyroidism, complementary examinations such as blood test, serum biochemical profile, chest radiographic and electrocardiographic examinations must always be made, since concomitant affections or diseases mimicking hyperthyroidism might interfere in the interpretation of hormonal doses (THODAY \& MOONEY, 1992).

Despite the inclusion of the routine in commercial biochemical profile, until this moment, there are no studies evaluating the diagnostic value of CK serum activity in cats with hyperthyroidism or its correlation with the serum activity of other enzymes. The aim was to evaluate $\mathrm{CK}$ serum activity in cats with hyperthyroidism and its association with thyroidal hormones and clinical-pathological alterations.

\section{MATERIALS AND METHODS}

This study included 19 cats with diagnosis of feline hyperthyroidism. Blood test, urine test, serum biochemical profile, chest x-ray, echocardiography and thyroidal function evaluation were performed. The average age of the cats was 12 years (interval of
9 to 15 years). From these, 7 were unneutered males (36.84\%), 4 neutered males $(21.05 \%), 5$ castrated females $(26.33 \%)$ and 3 non-castrated females (15.78\%). Only 3 cats had defined breeds - 2 Siamese and 1 Persian.

The animals admitted in the study were from different locations in the state of Paraná with spontaneous hyperthyroidism confirmed by the increase in serum concentration of TT4, FT4 or TT4 and FT4 and also by serum biochemical analysis, including the activity of CK, ALT, FA, AST, GGT, cholesterol and bile acids. The reference value for CK considered in this study was of $110-250 \mathrm{U} \mathrm{L}^{-1}$ (KANEKO et al., 2008). The animals whose serum samples were haemolysed and had an increase in serum bilirubin were excluded. The data extracted from the medical charts included history, physical examination and laboratorial tests (serum biochemical analysis, urinalysis and blood count), and the presence of previous anaesthesia or intramuscular injections. The presence or absence of thyrotoxic heart disease was determined by specific examination, which included electrocardiography, chest radiography and echocardiography. None of the cats selected had been submitted to intramuscular injection in the period of 10 days before the diagnostic of hyperthyroidism. Furthermore, there were other systemic diseases associated with hyperthyroidism. The cats were treated at the same place and all laboratory tests were carried out and hormonal at the same location and with the same methodology.

The samples for serum biochemical analyses were collected in test tubes and were kept at room temperature for 30 minutes to coagulate, and then were centrifuged. Sera were prepared and immediately analysed, or stored at $4^{\circ} \mathrm{C}$ for analysis in a period of up to $24 \mathrm{~h}$ from collection, using a SemiAutomatic Biochemical Analyzer (TP-Analyzer Plus, Brazil) and appropriate commercial kits.

The measurement of CK serum concentrations was performed and used in conjunction with SYNCHRON LX ${ }^{\circledR} \quad$ System (Beckman Coulter, Galway, Ireland). CK reagent is used to measure the CK activity by an enzymatic rate method. In the reaction creatine kinase catalyzes the transfer of a phosphate group from the creatine phosphate substrate to adenosine diphosphate (ADP). The subsequent formation of adenosine triphosphate (ATP) is measured through the use of two coupled reactions catalyzed by hexokinase (HK) and glucose6-phosphate dehydrogenase (G6PDH) which results in the production of reduced $\beta$-nicotinamide adenine dinucleotide phosphate (NADPH) from 
$\beta$-nicotinamide adenine dinucleotide phosphate (NADP). The CK assay contains the activator monothioglycerol.

The measurement of TT4 and FT4 serum concentrations was performed by radio immune essay (RIE) in solid phase for, using commercial kit validated for use in cats (Coat-Count Total T4 and Free T4, DPC, Los Angeles, USA) in Laboratory of Endocrinology and Reproduction, School of Veterinary Medicine and Animal Science, Botucaut$\mathrm{SP}$. The protocols recommended by the manufacturers for the measurements were not changed, and the reference values for TT4 and FT4 are of 11.6$51.54 \mathrm{nmol} \mathrm{L}^{-1}$ and $14.2-51.5 \mathrm{pmol} \mathrm{L} \mathrm{L}^{-1}$, respectively (FELDMAN \& NELSON, 2004). The test detects

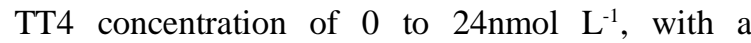
minimum sensitivity described of $0.25 \mathrm{nmol} \mathrm{L}^{-1}$. The test detects FT4 concentration of 0 to $10 \mathrm{pmol} \mathrm{L}^{-1}$, with a minimum sensitivity described of $0.15 \mathrm{pmol} \mathrm{L}^{-1}$.

The normality of variables was evaluated by the Kolmogorov-Smirnov test and then submitted to the variance analysis, measuring the effect of the heart disease on the variables. When $\mathrm{P}<0.05$, Tukey test was used to compare differences in the averages among groups of cats with and without heart diseases. In order to evaluate the relation of CK serum activity with the remaining variables within each group, a regression analysis was performed. Pearson and Spearman correlations were calculated for the parametric and non-parametric variables, respectively. The correlations were considered weak when $r<0.5$ and moderate when $r=0.5-0.75$. For all tests applied, $\mathrm{P} \leq 0.05$ was considered statistically significant. All calculations were performed using the statistic software (Statica 7 for Windows, SPSS, USA).

\section{RESULTS}

The elevation of serum concentrations of TT4 (34.88-294.98nmol L-1) and free T4 (2.83$52.9 \mathrm{pmol} \mathrm{L} \mathrm{L}^{-1}$ ) were used to confirm the diagnostic of spontaneous hyperthyroidism. The values of clinicalpathological findings from the 19 cats with spontaneous hyperthyroidism are described in table 1.

Average CK serum activity was $312.74 \mathrm{U}$ $\mathrm{L}^{-1}$ ranging from 136 to $873 \mathrm{U} \mathrm{L}^{-1}$. Nine $(47.3 \%)$ from the 19 cats presented an increase in CK activity, and from these, only two increases three times greater than the normal value. These two animals presented cardiomyopathy. There were no differences in $\mathrm{CK}$ serum activity in relation to age, gender or breed. CK activity was higher $(\mathrm{P}=0.048)$ in cats with hypertrophic cardiomyopathy secondary to thyrotoxicosis (Figure 1). Among the cats with normal serum activity for creatine kinase, four presented echocardiographic cardiac alterations.

There was no statistical difference among the serum activity of ALT, AST, GGT and FA among the cats with increased CK serum activity and those with CK within normal values (Table 1). CK presented weak positive association with all the variables analysed in cats with or without heart conditions. In cats with heart conditions, creatine kinase presented a weak negative association with the values for TT4 (Figure 2), which has not happened with the cats without heart conditions for TT4 (Figure 3)

\section{DISCUSSION}

CK serum activity is routinely evaluated in cats. However, there is few studies evaluation the frequency of its elevation. Only one study evaluated its diagnostic and prognostic value, or its association with specific diagnoses (HOFFMANN \& SOLTER, 2008; STOCKHAM \& SCOTT, 2008; AROCH et al., 2010), and hyperthyroidism does not feature among them.

In our study, CK serum activity was evaluated in 19 cats diagnosed with hyperthyroidism. CK activity was higher than $250 \mathrm{U} \mathrm{L}^{-1}$ in $47.3 \%$ (9) of them. From these, two presented values above $500 \mathrm{U} \mathrm{L}^{-1}$ and presented cardiomyopathy secondary to thyrotoxicosis. In five cats $(55.55 \%)$ with increased CK serum activity, and in four $(40 \%)$ cats with normal CK activity, cardiac hypertrophy was detected in echocardiographic examination.

In $40 \%$ of cats with hyperthyroidism and with increased $\mathrm{CK}$, no muscular or cardiac alteration was detected, despite the high specificity of this enzyme to indicate these types of lesions. Probably, the serum measurement of CK, without its fractions, is not sufficient to indicate the presence of cardiac lesion. However, the measurement of CK isoenzymes was not the object of this study. Moreover, no diseases were identified in our cats associated to hyperthyroidism which could increase the CK serum activity, as described by AROCH et al. (2010). These authors have identified elevation in CK serum activity in several diseases, such as infectious diseases, kidney diseases, inflammatory diseases, hepatic lipidosis, trauma and neoplasia, among others. Protein catabolism and hypermetabolic state provoked by hyperthyroidism is probably the main cause of increase in the CK serum activity, despite the weak association between $\mathrm{CK}$ and thyroid hormones.

Many hyperthyroid cats have clinical evidence of heart disease. In addition, the various 
Table 1 - Serum concentration of creatine kinase, ALP, ALT, AST, GGT, total protein, globulin, albumin, total thyroxin (TT4) and free thyroxin (FT4) in cats with hyperthyroidism with or without cardiac changes.

\begin{tabular}{|c|c|c|c|c|}
\hline & & Mean \pm SD (Range) & Median & $\mathrm{P}$ \\
\hline \multirow{3}{*}{ Creatine kinase $\left(\mathrm{mg} \mathrm{dL}^{-1}\right)$} & Cardiac changes & $449,13^{a} \pm 280,22(188-873)$ & 377 & \multirow{3}{*}{0,048} \\
\hline & Without cardiac changes & $247,30^{\mathrm{b}} \pm 90,13(136-456)$ & 236,5 & \\
\hline & Total & $312,74 \pm 211,09(136-873)$ & 262 & \\
\hline \multirow{3}{*}{$\begin{array}{l}\text { ALP } \\
\left(\mathrm{mg} \mathrm{dL}^{-1}\right)\end{array}$} & Cardiac changes & $76,29 \pm 38,1(28-141)$ & 72 & \multirow{3}{*}{0,701} \\
\hline & Without cardiac changes & $70,7 \pm 20,93(45-108)$ & 71 & \\
\hline & Total & $73 \pm 28,6(28-141)$ & 72 & \\
\hline \multirow{3}{*}{$\operatorname{ALT}\left(\mathrm{mg} \mathrm{dL}^{-1}\right)$} & Cardiac changes & $165,57 \pm 150,17(52-471)$ & 96 & \multirow{3}{*}{0,29} \\
\hline & Without cardiac changes & $109,8 \pm 52,2(58-201)$ & 100 & \\
\hline & Total & $132,76 \pm 103,87(52-471)$ & 96 & \\
\hline \multirow{3}{*}{ AST $\left(\mathrm{mg} \mathrm{dL}^{-1}\right)$} & Cardiac changes & $43,71 \pm 22,19(23-88)$ & 36 & \multirow{3}{*}{0,18} \\
\hline & Without cardiac changes & $33,4 \pm 6,4(24-47)$ & 32,5 & \\
\hline & Total & $37,65 \pm 15,33(23-88)$ & 34 & \\
\hline \multirow{3}{*}{ Total protein $\left(\mathrm{g} \mathrm{L}^{-1}\right)$} & Cardiac changes & $7,2 \pm 1,02(6,3-9,3)$ & 7 & \multirow{3}{*}{0,705} \\
\hline & Without cardiac changes & $7,03 \pm 0,8(5,7-8,5)$ & 7,20 & \\
\hline & Total & $7,1 \pm 0,87(5,7-9,3)$ & 7 & \\
\hline \multirow{3}{*}{ Albumin $\left(\mathrm{g} \mathrm{L}^{-1}\right)$} & Cardiac changes & $2,94 \pm 0,21(2,6-3,2)$ & 2,9 & \multirow{3}{*}{0,508} \\
\hline & Without cardiac changes & $3,01 \pm 0,2(2,6-3,3)$ & 3,1 & \\
\hline & Total & $2,98 \pm 0,2(2,6-3,3)$ & 3,1 & \\
\hline \multirow{3}{*}{ Globulin $\left(\mathrm{g} \mathrm{L}^{-1}\right)$} & Cardiac changes & $4,26 \pm 1,15(3,3-6,7)$ & 3,9 & \multirow{3}{*}{0,753} \\
\hline & Without cardiac changes & $4,1 \pm 0,88(2,8-5,7)$ & 4,3 & \\
\hline & Total & $4,16 \pm 0,97(2,80-6,70)$ & 4,30 & \\
\hline \multirow{3}{*}{ TT4 (nmol L $\left.{ }^{-1}\right)$} & Cardiac changes & $173,99 \pm 70,52(70,27-294,98)$ & 183,59 & \multirow{3}{*}{0,26} \\
\hline & Without cardiac changes & $140,34 \pm 54,33(34,88-198,97)$ & 151,74 & \\
\hline & Total & $154,51 \pm 62,17(34,88-294,98)$ & 174 & \\
\hline \multirow{3}{*}{ FT4 $\left(\right.$ pmol L $\left.{ }^{-1}\right)$} & Cardiac changes & $24,05 \pm 11,15(8,24-43,63)$ & 25,48 & \multirow{3}{*}{0,90} \\
\hline & Without cardiac changes & $23,32 \pm 14,11(2,83-52,9)$ & 23,6 & \\
\hline & Total & $23,63 \pm 12,61(2,83-52,9)$ & 24,45 & \\
\hline
\end{tabular}

ALP: alkaline phosphatase, ALT: alanine aminotransferase, AST: aspartate aminotransferase, GGT: $\gamma$-glutamyl transferase $(\mathrm{P}<0,05)$.

findings, ascribed to cardiac disease make identification of these abnormalities relatively common. The common cardiovascular abnormalities include systolic murmurs, tachycardia, and gallop rhythms. Less commonly, arrhythymias and signs of congestive heart failure may be detected. Signs of failures include dyspnea, muffled heart sounds, and ascites. Furthermore, tachycardia in cats is common finding (heart rates greater than 240 beats per minute) (MOONEY \& PETERSON, 2004). Hyperthyroidism in cats can induce a variety of cardiac-related disturbances, most notably secondary cardiomyopathies. Hypertrophic cardiomyopathies are much more common in these cats than the dilated type (FELDMAN \& NELSON, 2004).

Hyperthyroidism can result in vascular resistance low and in low cardiac output high. This condition is due to the direct effects of thyroid hormone on cardiac muscle plus interactions between thyroid hormone and the sympathetic nervous system. The high-output state is also enhanced by increased metabolic rates and oxygen requirements in various tissues (FELDMAN \& NELSON, 2004).

CK is useful in the interpretation of serum activity for AST, ALT and LDH (HOFFMANN \& SOLTER, 2008; STOCKHAM \& SCOTT, 2008). In 


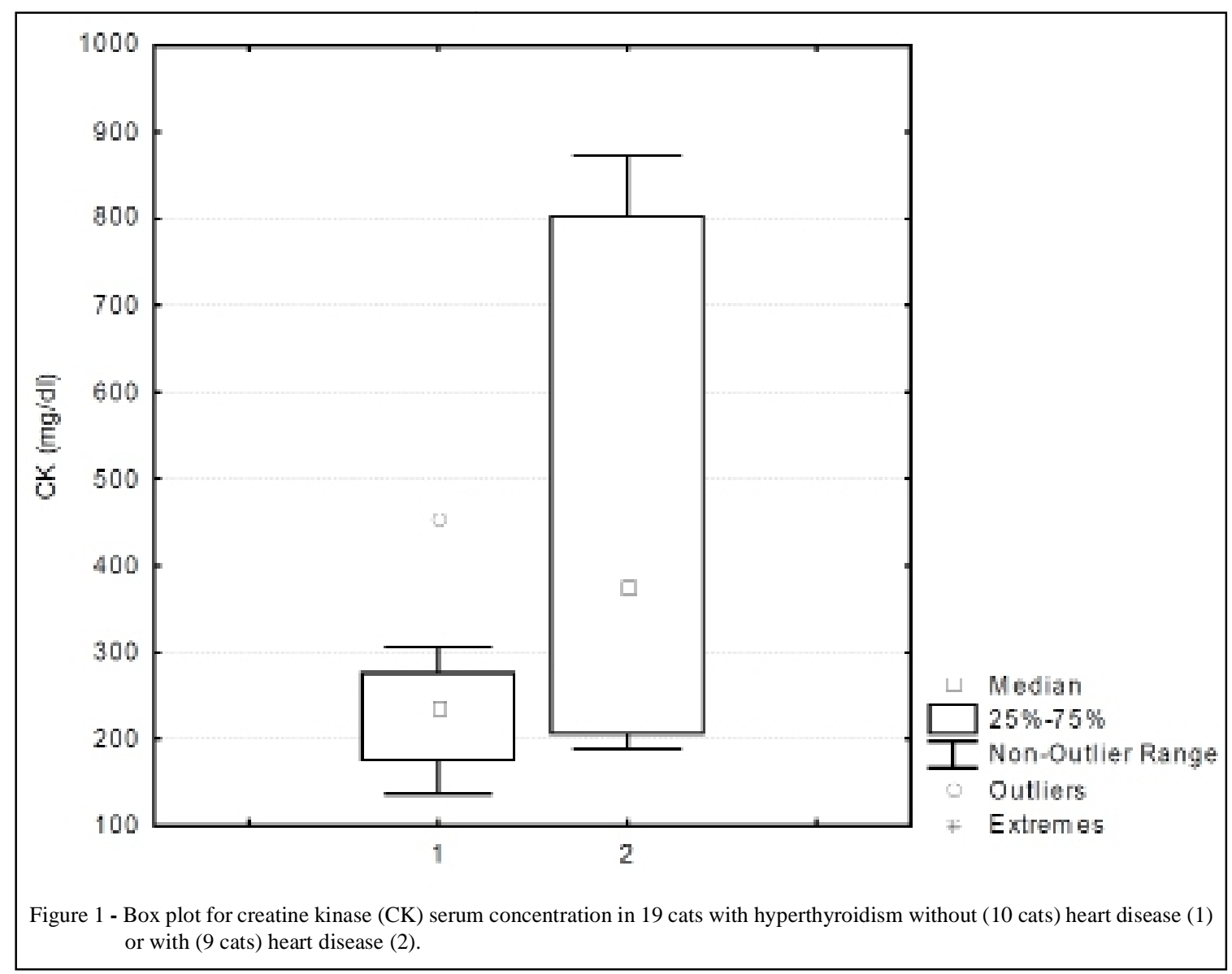

the cats studied, there was a weak association among CK, ALT and AST, and a moderate association between AST and ALT. This correlation possibly reflects damages to the liver, since these enzymes increase their serum activity when there is hepatocellular lesion, mainly ALT, which is considered the most hepatic-specific (HOFFMANN \& SOLTER, 2008; STOCKHAM \& SCOTT, 2008). The possibility of hepatic lesions in patients with hyperthyroidism is common, and it probably contributes to the increase in serum activities for AST and ALT (SHIEL \& MOONEY, 2007).

Cats with hyperthyroidism often have high serum activities of liver-derived enzymes. Approximately $75 \%$ of cats have high serum alkaline phosphatase (SAP) and alanine aminotransferase (ALT) activities, and more than $90 \%$ have increases in at least one of these enzymes (BROUSSARD et al., 1995; HORNEY et al., 1995). Usually serum activity of liver-derived enzymes is only mildly high, although dramatic increases in ALT and SAP activities have been documented. The etiology of increases in serum liver enzyme activities in cats with hyperthyroidism is unknown. Various causes of hepatocyte damage in animals with hyperthyroidism have been investigated, though little information is available for cats. Ultrastructural and functional changes in hepatocyte mitochondria have been documented in rats who are thyrotoxic including T3 associated mitochondrial-induced apoptosis and oxidative hepatic deoxyribonucleic acid damage because of lipid peroxidation, protein oxidation, and glutathione depletion (BERENT et al., 2007).

Feline studies have shown that the bone alkaline phosphatase (ALP) isoenzyme is high in the serum of cats with hyperthyroidism and that both the liver and bone isoenzymes contribute to the high ALP activity in the serum of cats with hyperthyroidism (ARCHER \& TAYLOR, 1996; CARDOSO et al., 2008).

The simultaneous increase of $\mathrm{CK}$ and AST is an indication of muscular lesions. However, this fact apparently has not been observed in the 19 hyperthyroidal cats. The increase of CK and AST indicating muscular lesion in cats was described in other studies (FASCETTI et al., 1997; AROCH et al., 2010), but none of the animals had hyperthyroidism. 


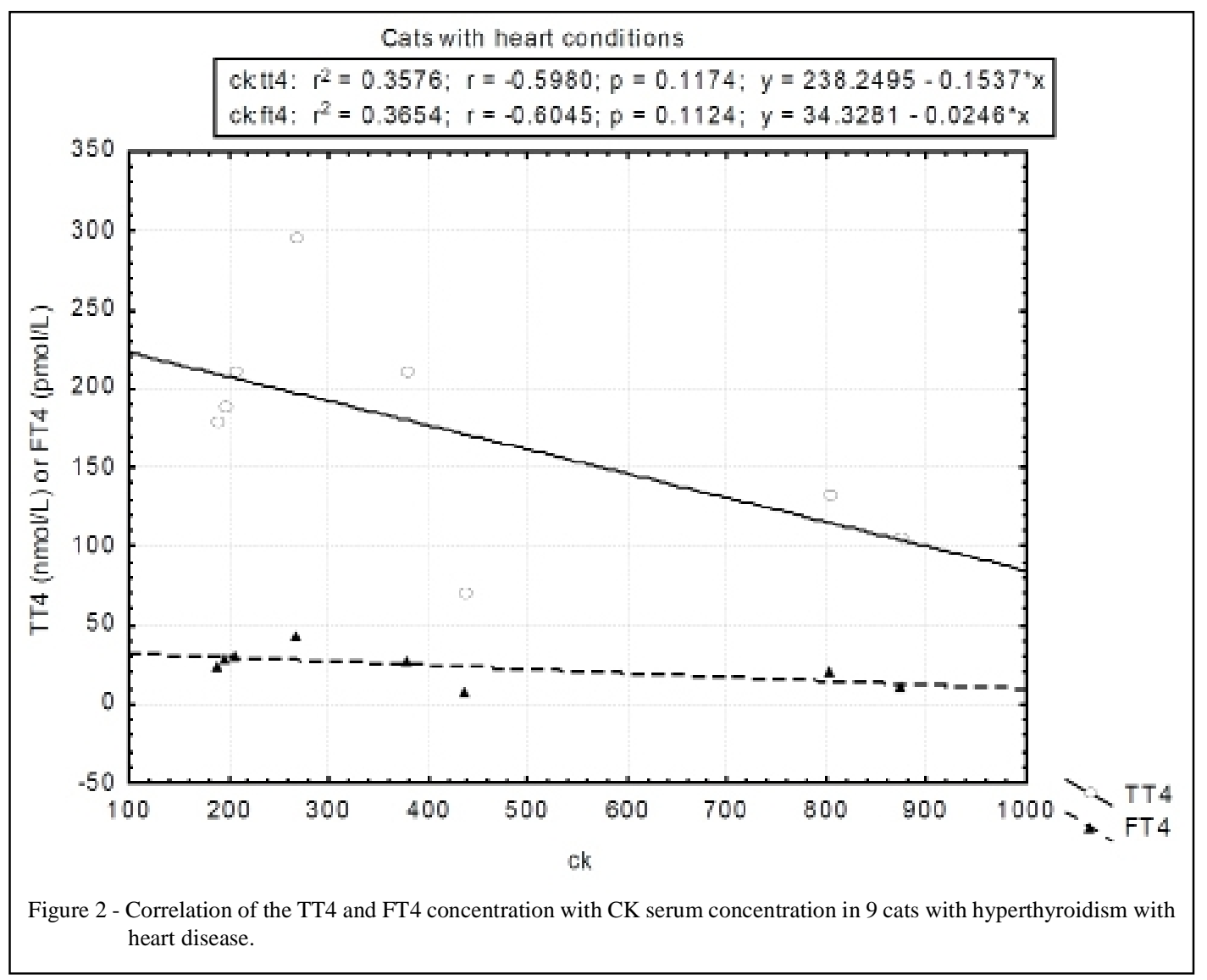

Four cats presenting cardiac alteration also had a mild increase (less than 5-fold the normal value) in CK serum activity. In humans, a severe muscular lesion such as rhabdomyolysis is biochemically characterized by myoglobinaemia, myoglobinuria and increase in serum levels of muscular enzymes (in the absence of myocardial lesion), particularly of CK (increase above 5-fold the normal value) (MELLI \& CHAUDHRY, 2005; AROCH et al., 2010). In this study, this relation was not identified. Since the increase in CK was mild, values of serum and urinary myoglobulin were not measured, and, also, the two cases with elevated activity were cardiac. Therefore, this human criterion could not be used in this study. The extremely increased CK activity in cats with severe disease was associated such as more elevated mortality rate and bad prognosis. However, this was not described in cats with hyperthyroidism (AROCH et al., 2010) and was identified in this study.

Polyuria, polydipsia and secondary hypokalemia are frequent in cats with hyperthyroidism (SHIEL \& MOONEY, 2007). Hypokalemia is an important cause of lesion in the skeletal muscle and rhabdomyolysis in humans, dogs and cats
(SHELTON, 2005; GOTO et al., 2009). Moreover, potassium has an important mechanism in elevating the serum activity of CK in hypokalemic myopathy and in hyperaldosteronism (ROSE et al., 2007; SHELTON, 2005; NEMZEK et al., 1994). In the animals studied, hypokalemia and myopathy were not observed.

AROCH et al., (2010) state that the mild to moderate increase in CK serum activity in sick cats is difficult to explain. Probably in cats with hyperthyroidism, hypo-perfusion and chronic ischemia in skeletal muscle caused by the hyperthyroidal state contributed to the increase in the serum activity of CK. Due to the retrospective nature of the study, it is difficult to identify factors that can also have been responsible for the increase in $\mathrm{CK}$ activity, such as traumas, contention for performance of examinations, traumatic vein puncture, permanence in cages, physical effort or prolonged recumbence. Anorexia (FASCETTI et al., 1997), present in some hyperthyroidism cases, could have contributed positively to the increase in $\mathrm{CK}$, since it is associated to the increase of muscular catabolism, due to the negative energetic valance. Also, the daily routine of 


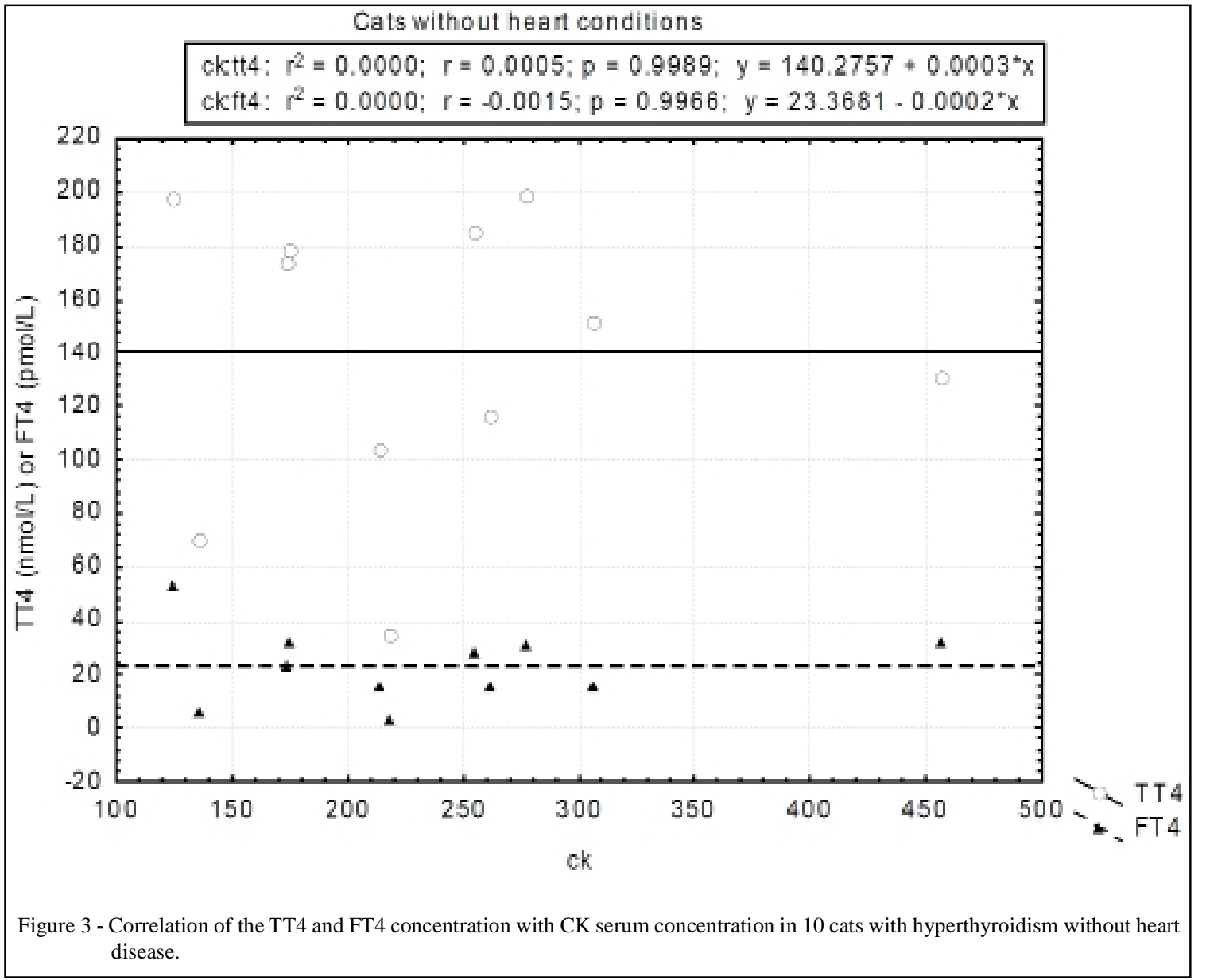

animals was not monitored due to the retrospective nature of the study.

Intramuscular injections have been documented as causes of increase in CK serum activity in dogs, cats, sheep, horse and cattle in several studies. However, in this study, it is known that the animals have not been submitted to intramuscular injections 10 days before the diagnosis of hyperthyroidism (AKTAS et al., 1995; LEFEBVRE et al., 1996; HOFFMANN \& SOLTER, 2008; STOCKHAM \& SCOTT, 2008; AROCH et al., 2010).

The increase in CK serum activity was a frequent finding in cats with cardiomyopathies and arterial thromboembolism, the latter with highest elevation (AROCH et al., 2010). From the 19 cats studied, nine presented cardiomyopathy and only five had mild to moderate elevation of CK serum activity. Probably, ischemia of myocardium and progressive and chronic myocardial disease caused by thyrotoxicosis have contributed to the increase in $\mathrm{CK}$ activity. The measurement of $\mathrm{CK}$ isoenzymes (CK$\mathrm{MB} / \mathrm{CK} 2$ ) and serum cardiac troponins would help in elucidating the origin of the CK serum activity; however, they were not the objects of this study. Added to this, CK short half-life (HOFFMANN \& SOLTER, 2008) and/or absences of acute lesions made not all cats with heart disease present increase in $\mathrm{CK}$.

The retrospective characteristic of this study, deficiencies in the medical records and the reduced number of animals has limited a better statistical analysis. Since it is an extremely sensitive enzyme, it would be necessary to have a strict control of the routine of these animals in order to notice changes capable of increasing CK levels or not, as well as hyperthyroidism. Other studies have proven that the increase in CK activity is intimately related to the severity of the disease (AROCH et al., 2010), but this was not the object in this study. The increase in CK serum activity in $47.3 \%$ cats with hyperthyroidism makes it necessary to include its analysis in feline patient with suspicion of thyroid disease so that further studies can be performed, with the objective of proving this correlation. In this study, 
it was not possible to establish a clear association between hyperthyroidism and CK increase. However, it is important to notice the inclusion of CK activity in routine examinations to evaluate hyperthyroidism and so that new studies can be performed.

\section{ETHICS AND BIOSAFETY COMMITTEE}

This study was approved by the Ethics board of the Faculdade de Medicina Veterinária e Zootecnia (FMVZ) animal experiments, Universidade Estadual Paulista (UNESP), Botucatu, SP, Protocol 63/2002-CEEA, December $10^{\text {th }}, 2002$, and is in accordance with the ethical principles of animal experimentation (COBEA)

\section{ACKNOWLEDGEMENTS}

The authors would like to thank Araucaria Foundation and National Research Council $(\mathrm{CNPq})$ for the financial support for this research.

\section{REFERENCES}

AKTAS, M. et al. Disposition of creatine kinase activity in dog plasma following intra-venous and intramuscular injection of skeletal muscle homogenates. Journal Veterinary Pharmacology Therapeutics, v.18, n.1, p.1-6, 1995. Available from: <http:// onlinelibrary.wiley.com>. Accessed: july 05, 2013. doi: 10.1111/ j.1365-2885.1995.tb00542.x

ARCHER, F.J.; TAYLOR, S.M. Alkaline phosphatase bone isoenzyme and osteocalcin in the serum of hyperthyroid cats. Canadian Veterinary Journal, v.37, p.735-739, 1996.

AROCH, I. et al. Diagnostic and prognostic value of serum creatine-kinase activity in ill cats: a retrospective study of 601 cases. Journal of Feline Medicine and Surgery, v.12, n.6, p.466475, 2010. Available from: <http://onlinelibrary.wiley.com.> Accessed: july 05, 2012. doi: 10.1111/j.1939-165X.2010.00242.x.

BROUSSARD, J.D. et al. Changes in the clinical and laboratory findings in hyperthyroid cats from 1983 to 1993. Journal American Veterinary Medical Association, v.206, p.302-305, 1995.

BERENT, A. et al. Liver function in cats with hyperthyroidism before and after ${ }_{131} \mathrm{I}$ therapy. Journal Veterinary Internal Medicine, v.11, n.1, p.9-13, 2007. Available from: <http:// onlinelibrary.wiley.com>. Accessed: july 05, 2012. doi: 10.1111/ j.1939-1676.2007.tb01941.x

CARDOSO, M.J.L. et al. Marcadores do metabolismo ósseo no hipertireoidismo felino. Ciência Rural, v.38, n.5, p.13681374, 2008. Available from: <http://www.scielo.br/pdf/cr/v38n5/ a27v38n5.pdf>. Accessed: Jul. 05, 2012. doi: 10.1590/S010384782008000500027 .

CARDOSO, M.J.L. et al. Manifestações clínicas em gatos com hipertireoidismo experimental. Archives of Veterinary Science, v.10, n.2, p.135-140, 2005. Available from: <http://ojs.c3sl.ufpr. br/ojs2/index.php/veterinary/article/view/4429/3473>. Accessed: july. 05, 2012.
DINIZ, P.P.V.P. et al. Cardiac trauma confirmed by cardiac markers in dogs: two case reports. Arquivos Brasileiros de Medicina Veterinária e Zootecnia, v.59, n.1, p.85-89, 2007. Available from: <http://www.scielo.br/scielo.php?pid=S010209352007000100015\&script=sci_arttext\&tlng=en>. Accessed: july. 05, 2012. doi: 10.1590/S0102-09352007000100015.

FASCETTI, A.J. et al. Correlation between serum creatine kinase activities and anorexia in cats. Journal Veterinary Internal Medicine, v.11, n.1, p.9-13, 1997. Available from: <http:// onlinelibrary.wiley.com>. Accessed: july. 05, 2012. doi: 10.1111/ j.1939-1676.1997.tb00066.x.

GOTO, A. et al. Primary aldosteronism associated with severe rhabdomyolysis due to profound hypokalemia. Internal Medicine, v.48, n.4, p.219-223, 2009. Availble form: <http://www. naika.or.jp/imonline/>. Accessd: july. 05, 2012. doi: 10.2169/ internalmedicine.48.1444

HOFFMANN, W.E.; SOLTER, P.F. Diagnostic enzymology of domestic animals. In: KANEKO, J.J. et al. (Ed.). Clinical biochemistry of domestic animals. San Diego: Academic, 2008. p.351-378.

HORNEY, B.S., et al. Agarose gel electrophoresis of alkaline phosphatase isoenzymes in the serum of hyperthyroid cats. Veterinary Clinics Pathology, v.23, p.98-102, 1995.

LEFEBVRE, H.P. et al. Non-invasive and quantitative evaluation of post-injection muscle damage by pharmacokinetic analysis of creatine kinase release. Veterinary Research, v.27, n.4-5, p.343361, 1996.

LEVY, J.K. et al. Effect of age on reference intervals of serum biochemical values in kittens. Journal American Veterinary Medical Association, v.228, n.7, p.1033-1037, 2006. Available from: <http://avmajournals.avma.org/doi/abs/10.2460/javma.228.7.1033>. Accessed: july. 05, 2012. doi: 10.2460/javma.228.7.1033.

LIMA, J.G. et al. Influência da função tireoidiana nos níveis séricos de CPK. Arquivos Brasileiros Endocrinologia \& Metabologia, v.56, n.3, p.190-194, 2012. Available from: <http://www.scielo.br/ scielo.php?pid=S0004-27302012000300007\&script=sci_arttext $>$. Accessed: Apr. 15, 2012. doi: 10.1590/S0004-27302012000300007.

McGROWDER, D.A. et al. Serum creatine kinase and lactate dehydrogenase activities in patients with thyroid disorders. Nigerian Journal Clinical Practice, v. 14, p.454-459, 2011.

MELLI, G. et al. Rhabdomyolysis: an evaluation of 475 hospitalized patients. Medicine, v.84, n. 6, p.377-385, 2005

MOONEY, C.T.; PETERSON, M.E. Feline hyperthyroidism. In: Manual of canine and feline endocrinology. 3.ed. England: BSAVA, 2004. p.95-111.

MOONEY, C.T. et al. Serum thyroxine and triidothyronine responses of hyperthyroid cats to thyrotropin. American Journal Veterinary Research, v.57, n.7, p.987-991, 1996.

NEMZEK, J.A. et al. Acute onset of hypokalemia and muscular weakness in four hyperthyroid cats. Journal American Veterinary Medical Association, v.205, p.65-68, 1994.

PETERSON, M.E et al. Measurement of serum total thyroxine, triidothyronine, free thyroxine, and thyrotropin concentrations 
for diagnosis of hypothyroidism in dogs. Journal American Veterinary Medical Association, v.211, p.1396-402, 1997.

ROSE, S.A. et al. Adrenalectomy and cavalthrombectomy in a cat with primary hyperaldosteronism. Journal American Animal Hospital Association, v.43, n.4, p.209-214, 2007.

SHELTON, G.D. Rhabdomyolysis, myoglobinuria, and necrotizing myopathies. Veterinary Clinicis North American Small Animal Practice, v.34, n.6, p.1469-1482, 2004. Available from: <http:// www.sciencedirect.com/science/journal/01955616>. Accessed: july. 05, 2012. doi: 10.1016/j.cvsm.2004.05.020.
SHIEL, R.E.; MOONEY, C.T. Testing for hyperthyroidism in cats. Veterinary Clinics of North America: Small Animal Practice, v.37, n.4, p.671-691, 2007. Available from: <http://www. sciencedirect.com/science/journal/01955616>. Accessed: july. 05, 2012. doi: 10.1016/j.cvsm.2007.03.006.

STOCKHAM, S.L.; SCOTT, M.A. Enzymes. In: STOCKHAM, S.L.; SCOTT, M.A. (Ed.). Fundamentals of veterinary clinical pathology. Ames: Wiley-Blackwell, 2008. p.640-674.

THODAY, K.L.; MOONEY, C.T. Historical clinical and laboratory features of 126 hyperthyroid cats. Veterinary Record, v.131, p.257-264, 1992.

Ciência Rural, v.44, n.12, dez, 2014. 